\title{
HUBUNGAN PATRON-CLIENT DAN RITUAL PETIK LAUT - Studi Kasus Masyarakat Desa Tanjung Luar, Kabupaten Lombok Timur, Nusa Tenggara Barat
}

\author{
Oleh Nurbayu Sutiya Rahmi \\ Program Magister Sumber Daya Pantai Universitas Diponegoro
}

\begin{abstract}
Tanjung Luar village, located in East Lombok regency, is around $222 \mathrm{~km}^{2}$ and has good potential fishery. Continual exploitation at Tanjung Luar village with using of inefficient fishing capture would decrease the existing resource abundance. Patron-client in Tanjung Luar village society forms a community group called "Kelompok Masyarakat Pengelola Laut" that manages the fishery resource. Tradition existence "Petik laut" also can help the fishery resource management at Tanjung Luar village, East Lombok Regency.
\end{abstract}

Key words: Patron-client, sea ritual, East Lombok, Nusa Tenggara Barat.

\section{Pendahuluan}

Potensi sumberdaya kelautan dan perikanan diyakini masih menjanjikan sebagai andalan kelangsungan hidup bangsa Indonesia. Keyakinan terhadap keandalan sumberdaya ini tidak lain karena sumberdaya ikan sebagai salah satu komponen hayati yang paling banyak dimanfaatkan dan dapat pulih kembali (renewable resources). Salah satunya adalah Kabupaten Lombok Timur yang merupakan salah satu kabupaten/kota yang ada di provinsi Nusa Tenggara Barat dengan panjang pantai $220 \mathrm{~km}$ dan luas lautnya $1.074,33 \mathrm{~km}^{2}$ sehingga memiliki potensi yang cukup besar dalam pengembangan usaha perikanan baik bagi perikanan tangkap maupun perikanan budidaya. Untuk memanfaatkan sumberdaya ikan secara optimum, diperlukan pengelolaan smberdaya kelautan dan perikanan yang dilakukan secara bijaksana. Selain itu diperlukan adanya komitmen dari pemangku kepentingan dan perilaku masyarakat yang mendukung pemanfaatan secara efisien dan lestari (BAPPENAS, 2005). 
Kehidupan ekonomi masyarakat pantai khususnya nelayan tergantung pada sumberdaya perikanan yang ada disekitar mereka. Eksploitasi yang terus-menerus dengan penggunaan alat yang efisien hanya akan memberikan keuntungan jangka pendek, karena lama-kelamaan sumberdaya perikanan akan semakin terdeplesi, akibatnya pendapatan masyarakat pantai/nelayan juga semakin berkurang. Apabila usaha penangkapan ini dilakukan secara terus-menerus akan dapat mengancam kelestarian sumberdaya perikanan karena apabila ikan-ikan ditangkap terus-menerus berarti tidak memberikan kesempatan bagi ikan-ikan untuk tumbuh pada ukuran-ukuran tertentu sehingga stok ikan di perairan menjadi terancam.

Pengelolaan sumberdaya perikanan berbasis masyarakat adalah salah satu proses pemberian wewenang, tanggung jawab, dan kesempatan kepada masyarakat untuk mengelola sumberdaya perikanan sendiri, tapi juga harus mengartikan kebutuhan dan keinginan, tujuan serta aspirasinya. Komponen sistem manusia dalam perikanan laut secara sederhana dapat dikelompokkan menjadi nelayan, rumah tangga, dan komunitasnya, pengolah (pasca panen) dan pedagang (pemasaran), serta lingkungan lingkungan sosial ekonomi. Komponen-komponen tersebut akan saling berinteraksi khususnya para nelayan (patron-client) dalam mempengaruhi pola pemanfaatan dan pengelolaan sumberdaya perikanan (Widodo dan Saudi, 2006).

\section{Pembahasan}

\section{1. Gambaran Umum Desa Tanjung Luar Kabupaten Lombok Timur}

Desa Tanjung Luar terletak dalam wilayah Kecamatan Keruak, Kabupaten Lombok Timur, Provinsi Nusa Tenggara Barat. Desa Tanjung Luar merupakan salah satu desa pantai di Kabupaten Lombok Timur dengan ketinggian $\pm 350 \mathrm{~m}$ dari permukaan laut 
dengan suhu rata-rata $31^{\circ} \mathrm{C}$ dan curah hujan berkisar antara 1.000-2.000 mm/tahun dengan jumlah curah hujan 74 (tujuh puluh empat) hari/tahun.

Luas wilayah Desa Tanjung Luar sekitar $222 \mathrm{~km}^{2}$, terdiri dari 10 (sepuluh) dusun yaitu Toroh Tengah, Toroh Selatan, Kampung Kokok, Kampung Baru, Kampung Tengah, Kampung Lungkak, Maringgik, Kampung Palebe, Telaga Bagek. Adapun batas-batas wilayah Desa Tanjung Luar adalah sebagai berikut. (1) Sebelah Selatan: Desa Jerowaru; (2) sebelah barat, Desa Selebung; (3) sebelah utara, Desa Pijot; dan (4) sebelah timur, Desa Alas.

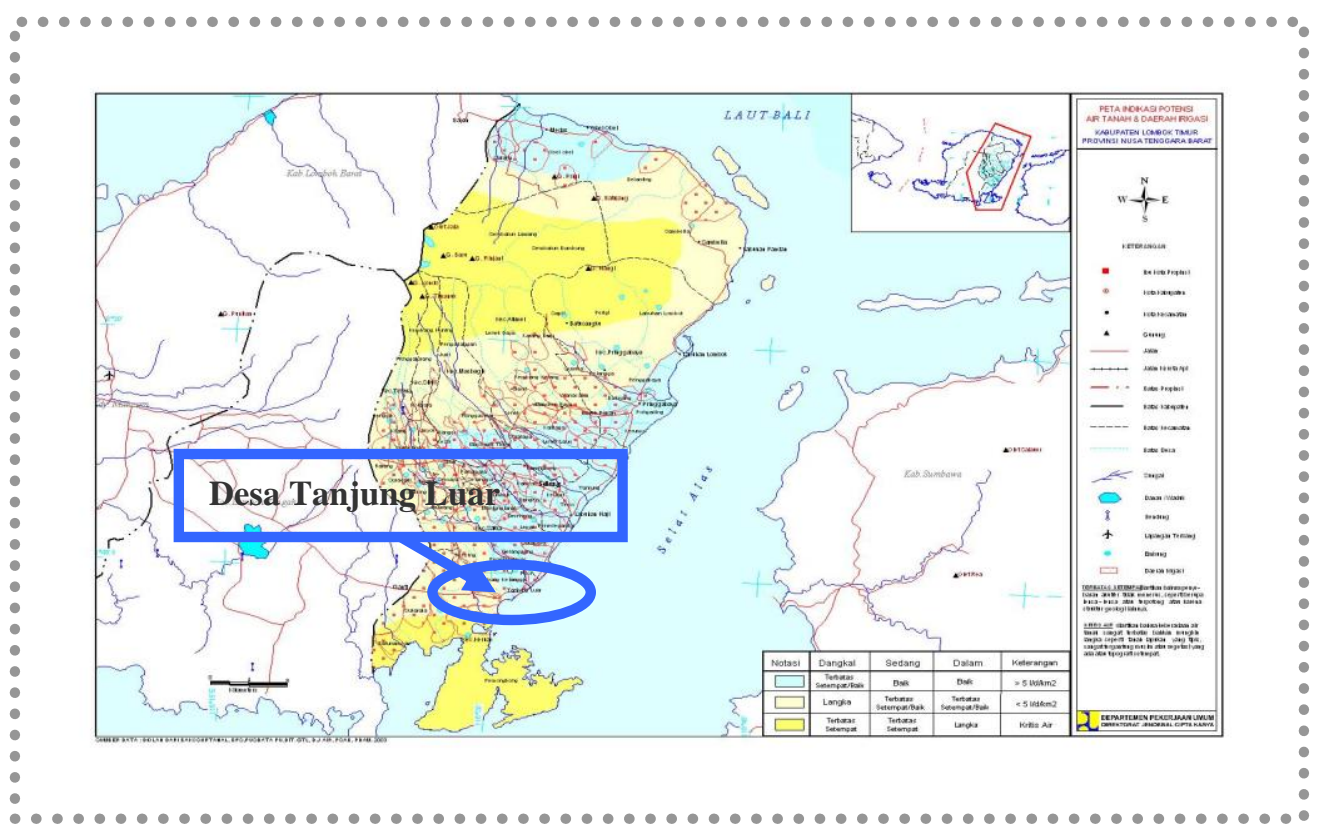

Gambar 1. Peta Kabupaten Lombok Timur dan Desa Tanjung Luar (Sumber gambar: www.google.com)

Luas wilayah desa Tanjung Luar sekitar $222 \mathrm{~km}^{2}$, terdiri dari 10 (sepuluh) dusun. Desa Tanjung Luar terletak cukup jauh dari Ibu kota Provinsi (Mataram), jarak ke Ibu kota Kabupaten 18 (delapan belas) km dan ke Ibu kota Kecamatan 3,5 (tiga setengah) km. Sebagian besar penduduk desa Tanjung Luar mencari nafkah sebagai nelayan, hal ini 
disebabkan karena kondisi alam desa Tanjung Luar merupakan daerah pantai sehingga menuntut masyarakat untuk lebih banyak bergerak dalam bidang perikanan, khususnya dalam perikanan laut. Sarana yang ada di desa Tanjung Luar antara lain: jalan raya, pasar umum, Pelabuhan Perikanan atau Pangkalan Pendaratan Ikan (PPI) dan lain-lain.

\section{2. Potensi Perikanan Desa Tanjung Luar Kabupaten Lombok Timur}

Kabupaten Lombok Timur adalah salah satu dari 7 (tujuh) kabupaten/kota yang ada di Provinsi Nusa Tenggara Barat dengan panjang pantai Kabupaten Lombok Timur adalah $220 \mathrm{~km}$ dan luas perairan laut $\pm 1.074 \mathrm{~km}^{2}$. Dari kondisi ini dapat diketahui bahwa Kabupaten Lombok Timur sangat potensial untuk pengembangan sumberdaya perikanan, baik perikanan tangkap maupun perikanan budidaya. Potensi sumberdaya lestari (Maximum Sustainable Yield) Kabupaten Lombok Timur pertahun adalah 11.400 ton/tahun yang terdiri dari potensi sumberdaya ikan pelagis 4.557 ton/tahun dan sumberdaya ikan demersal 6.843 ton/tahun. Pemanfaatan sumberdaya tersebut masih dalam skala kecil, artinya penangkapan yang dilakukan oleh masyarakat masih bersifat tradisional (Dinas Perikanan dan Kelautan Lombok Timur, 2004).

Perkembangan produksi perikanan khususnya yang didaratkan di PPI Tanjung Luar dari tahun ke tahun selalu mengalami perubahan, terkadang naik dan terkadang turun. Hal ini dipengaruhi oleh banyak faktor, di antaranya meliputi faktor biologi dan migrasi dari ikan, faktor unit penangkapan, faktor permintaan dan ketersediaan. Sebagai gambaran umum tentang keadaan perikanan di PPI Tanjung Luar, di bawah ini terdapat data perkembangan produksi jenis-jenis ikan yang didaratkan di PPI Tanjung Luar selama 9 (sembilan) tahun (1998-2006). Secara garis besar untuk melihat atau mengetahui tingkat 
kemampuan dari suatu usaha adalah melihat perkembangan produksi setiap tahun. Adapun perkembangan produksi ikan yang didaratkan di PPI Tanjung Luar adalah sebagai berikut.

Tabel 1. Perkembangan produksi ikan yang didaratkan di PPI Tanjung Luar (1998-2006)

\begin{tabular}{ccc}
\hline Tahun & $\begin{array}{c}\text { Jumlah Produksi } \\
(\mathrm{kg})\end{array}$ & Persentase $(\%)$ \\
\hline 1998 & 7.776 .951 & 27,23 \\
1999 & 7.957 .422 & 27,86 \\
2000 & 5.090 .850 & 17,82 \\
2001 & 2.666 .030 & 9,34 \\
2002 & 2.090 .182 & 7,32 \\
2003 & 788.019 & 2,76 \\
2004 & 524.591 & 1,84 \\
2005 & 668.004 & 2,34 \\
2006 & 996.838 & 3,49 \\
\hline Jumlah & 28.558 .887 & 100 \\
\hline
\end{tabular}

Sumber: Dinas Kelautan dan Perikanan Kabupaten Lombok Timur (2006)

\section{3. Pengertian Masyarakat Nelayan dan Patron-Client}

Masyarakat nelayan dapat diartikan sebagai kelompok masyarakat yang sebagian penduduknya mempunyai pekerjaan sebagai nelayan atau semua penduduk yang bertempat tinggal di sebuah wilayah pantai yang sebagian besar mempunyai mata pencaharian yang bersumber pada perikanan hasil tangkapan (Badan Koordinasi Keluarga Berencana Nasional, 1994). Masyarakat nelayan dapat dipahami sebagai masyarakat yang semua atau sebagian besar dari warganya mempunyai mata pencaharian dengan menangkap ikan di laut dan perairan lainnya, dan kegiatan-kegiatan sekitar penangkapan ikan dan hasil laut lainnya, termasuk para pengepul rumput laut, kerang-kerangan, penyu dan usaha penangkapan di perairan umum.

Beberapa komunitas nelayan membentuk sebuah jaringan sosial (network) yang akhirnya dimapankan dalam wujud pranata, yang dikenal dengan pranata patron-client. Secara umum pranata patron dan client merupakan sebuah pranata yang lahir dari rasa 
saling percaya antara beberapa golongan komunitas nelayan yaitu golongan pemilik kapal (modal ekonomi) yang berperan sebagai patron dan golongan komunitas nelayan yang tidak memiliki modal ekonomi tetapi memiliki modal lainnya seperti keahlian dan tenaga. Golongan yang memiliki keahlian di antaranya nakhoda dan teknisi sedangkan yang memiliki modal tenaga adalah yang berperan sebagai pekerja selain nakhoda dan teknisi. Golongan yang memiliki modal keahlian dan tenaga ini biasanya dikenal dengan sebutan "buruh" yang berperan sebagai client. Golongan komunitas nelayan yang hanya mengandalkan modal tenaga inilah yang termasuk dalam kategori nelayan miskin, dan merupakan jumlah yang terbesar.

\section{4. Hubungan Patron-Client}

Hubungan patron-client merupakan kasus khusus dengan hubungan antara 2 (dua) orang atau 2 (dua) yang sebagian besar melibatkan persahabatan instrumental, di mana seseorang yang kedudukan sosialnya lebih tinggi (patron) menggunakan pengaruh dan sumberdaya yang dimilikinya untuk memberikan perlindungan dan keuntungan kepada

orang yang kedudukannya lebih rendah (client). Pada gilirannya client akan membalas pemberian tersebut dengan dukungan yang umum dan bantuan, termasuk jasa-jasa pribadi pada patron. Tujuan utamanya adalah kedua belah pihak melakukan hubungan patronclient (apapun status mereka) untuk saling mendapatkan keuntungan berupa barang, jasa dan sumberdaya. Pada dasarnya, patron-client berhubungan dengan mekanisme sebagai berikut.

(1) Hubungan di antara pelaku atau perangkat para pelaku yang menguasai sumberdaya yang tidak sama. 
(2) Hubungan yang bersifat khusus (particularistic), hubungan pribadi, dan sedikit banyak mengandung kemesraan (affectivity).

(3) Hubungan yang berdasarkan atas saling menguntungkan serta saling memberi dan menerima.

Meskipun seandainya dalam melaut nelayan tradisional tidak memiliki patron, nelayan tradisional ini tetap terkait dengan pranata patron-client dalam hal menjual hasil tangkapan ikan. Meskipun TPI masih ada di wilayah mereka, masih banyak nelayan tradisional yang tidak mau menjualnya ke TPI melainkan kepada seorang pemborong (patron). Alasan mereka menjual kepada patron adalah bukan semata-mata persoalan harga tetapi adanya jaminan keuangan (ekonomi) yang dapat diberikan patron bila musim paceklik tiba, atau pada saat nelayan tidak bisa melaut karena gangguan cuaca, sakit, dan sebagainya; atau juga pada saat nelayan membutuhkan uang untuk membeli peralatan menangkap ikan seperti jaring (Mulyadi, 2005).

\section{5. Sistem Kelembagaan di Bidang Pengelolaan Sumberdaya Perikanan}

Desa Tanjung Luar merupakan satu-satunya desa di Kecamatan Keruak yang langsung bersentuhan dengan pantai. Sebagaimana lazimnya kawasan pantai dan pesisir, yang selalu berkesan sebagai kampung nelayan yang miskin, terbelakang, kumuh dan anti perubahan, Desa Tanjung Luar tidak lepas dari predikat yang kurang menguntungkan itu. Kesan anti perubahan dan menolak teknologi baru juga masih dialami oleh masyarakat Tanjung Luar, karena itu di desa ini diperkenalkan teknologi baru.

Secara umum jika diamati perkembangan desa Tanjung Luar sejak 10 (sepuluh) tahun terakhir menunjukkan kemajuan yang menggembirakan, artinya ada sebuah perubahan yang cukup signifikan yang menyangkut kehidupan sosial, ekonomi dan 
lingkungan, namun masih ada hal yang cukup penting untuk diperhatikan di tengah upaya untuk meningkatkan kesejahteraan nelayan yaitu munculnya para nelayan, baik nelayan domestik maupun nelayan asing, yang menggunakan teknologi modern dan praktek ini perlahan-lahan dapat merugikan nelayan lokal yang masih menggunakan alat yang tradisional. Atas dasar inilah masyarakat Tanjung Luar membuat peraturan-peraturan yang dapat melindungi hak-hak mereka.

Salah satu hasil yang disepakati oleh masyarakat Kecamatan Keruak adalah dibentuknya "Kelompok Masyarakat Pengelola Laut" (KMPL), yang mempunyai pengaruh sangat besar bagi pengelolaan sumberdaya perikanan. Semua pihak sepakat, keberadaan lembaga ini penting dalam rangka menjembatani hubungan antara pemerintah dan nelayan yang ada di wilayah Kecamatan Keruak. Tugas dari KMPL adalah sebagai berikut.

(1). Mengawasi pelaksanaan awig-awig (ketentuan adat setempat).

(2). Melakukan pengamatan dan patroli laut.

(3). Melaporkan kecelakaan laut.

(4). Mengeluarkan perizinan baik bagi anggota maupun pendatang.

Tugas untuk mengawasi pelaksanaan awig-awig bisa dilakukan oleh KMPL, namun diperlukan juga kerjasama antara KMPL dengan lembaga adat yang diakui dalam komunitas masyarakat desa Tanjung Luar untuk mengatasi masalah jika ada pelanggaran terhadap awig-awig. Tugas pengamanan dan patroli laut juga perlu dilakukan dengan bekerjasama secara intensif dengan institusi keamanan seperti Kepolisian Laut, dan juga pengamanan swakarsa yang bermunculan di berbagai desa di Kecamatan Keruak. Tugas melaporkan kecelakaan laut sebenarnya secara tradisional telah dilakukan oleh masyarakat nelayan, hanya saja karena keterbatasan kemampuan dan teknologi yang dimiliki, 
seringkali kecelakaan yang menimpa nelayan terlambat ditangani. Kehadiran KMPL dengan segala sarana dan prasarana yang memadai cukup banyak membantu dalam mengatasi terjadinya kecelakaan laut.

Mengeluarkan perizinan bagi anggota atau pendatang adalah salah satu fungsi dari KMPL, namun secara yuridis KMPL tidak berhak untuk mengeluarkan perizinan. KMPL bukan instansi pemerintah yang bersifat struktural, perizinan yang berkaitan dengan pengelolaan sumberdaya ikan dan lingkungan tetap harus dilakukan oleh instansi yang berwenang sesuai dengan jenjang dan kewenangan yang dimiliki. KMPL merupakan hasil kesepakatan warga yang memperoleh legitimasi dari pemerintah, maka dalam rangka menetapkan prosedur perizinan bagi nelayan, KMPL diharapkan dapat berperan sebagai salah satu lembaga yang berfungsi memberikan rekomendasi bagi nelayan untuk memperoleh izin dari instansi yang berwenang. Kerjasama antara pemerintah dan KMPL penting dilakukan untuk mengontrol perilaku masyarakat nelayan.

\section{6. Keikutsertaan Nelayan Tanjung Luar dalam Upaya Pengelolaan}

\section{Sumberdaya Perikanan}

Keikutsertaan nelayan Tanjung Luar dalam upaya pengelolaan sumberdaya perikanan cukup tinggi (Astuti, 2008). Masyarakat nelayan Tanjung Luar, baik patron maupun client, sadar akan pentingnya menjaga kelestarian sumberdaya perikanan yang mereka miliki. Menjaga kebersihan lingkungan dan tidak menggunakan bom dalam mencari ikan merupakan suatu bentuk keikutsertaan dalam menjaga sumberdaya perikanan yang mereka miliki. Tidak dipungkiri bahwa penggunaan potasium atau bom tetap dilakukan di perairan Tanjung Luar, akan tetapi hal tersebut bukan dilakukan oleh nelayan Tanjung Luar itu sendiri melainkan oleh nelayan yang berasal dari daerah lain. Masyarakat Tanjung Luar 
akan menindak tegas apabila ada nelayan yang ketahuan menggunakan bom atau bahan sejenisnya.

Para nelayan Tanjung Luar sangat tergantung pada sumberdaya perikanan untuk memenuhi kebutuhan hidup sehari-hari sehingga keikutsertaan para nelayan dalam pengelolaan sumberdaya perikanan dapat dikatakan cukup tinggi dalam hal menjaga kelestarian sumberdaya perikanan. Mereka sangat bergantung pada hasil melaut karena mereka tidak mempunyai pekerjaan sampingan yang lain selain melaut karena kurangnya keterampilan yang mereka memiliki.

Pada tahun 2004, Dinas Perikanan dan Kelautan Kabupaten Lombok Timur pernah mengadakan penanaman mangrove bersama di desa Tanjung Luar, dan nelayan Tanjung Luar sangat antusias dalam mengikuti kegiatan tersebut. Di samping itu, masyarakat Tanjung Luar juga akan menindak tegas bagi para nelayan yang menangkap ikan dengan menggunakan bom atau potasium karena akan merusak terumbu karang yang ada di daerah tersebut. Mereka meyakini bahwa karang yang baik merupakan tempat ikan memijah. Selain dapat merusak habitat vital seperti terumbu karang tersebut, mereka juga percaya bahwa menangkap ikan dengan menggunakan bom akan membunuh semua ikan baik yang berukuran besar maupun yang berukuran kecil, baik yang sedang memijah atau pun yang tidak memijah. Mereka mengetahui apabila hal itu dilakukan secara terus-menerus akan dapat menghabiskan sumberdaya perikanan tersebut, padahal mereka hanya mengandalkan dari hasil melaut saja. Untuk itu, partisipasi mereka cukup tinggi dalam menjaga kelestarian sumberdaya perikanan yang mereka miliki, salah satunya dengan pelarangan penggunaan bom atau potasium. Kegiatan kerja bakti (bersih desa) juga rutin diadakan di desa Tanjung Luar terutama di lingkungan sekitar pantai untuk menjaga kebersihan desa. 


\section{7. Adat-Istiadat: "Petik laut"}

Adat-istiadat adalah tata-kelakuan berupa aturan-aturan yang mempunyai sanksi lebih keras. Adat-istiadat adalah ciptaan manusia yang sesungguhnya dan hanyalah dari hasil usahanya sendiri untuk mengubah dan membentuk susunan baru kepada pemberitahuan Tuhan sesuai dengan jasmani dan rohaninya (Kartodiarjo, 1994). Acara adat-istiadat yang berkaitan dengan pengelolaan sumberdaya perikanan masih ada di desa Tanjung Luar, yaitu adat-istiadat dengan penyelenggaraan acara "Petik laut." Acara Petik laut ini dibawa oleh nelayan suku Wajo ke desa Tanjung Luar yang berpusat di kampung Toroh, yang dilaksanakan untuk menghormati leluhur mereka yang menurut mereka dahulunya hilang di dekat dermaga; selain itu juga untuk mengungkapkan rasa syukur kepada Tuhan Yang Maha Esa atas rezeki yang mereka terima, agar diberi keselamatan dalam melaut, serta yang paling penting adalah keselamatan untuk mengelola sumberdaya perikanan di Desa Tanjung Kabupaten Lombok Timur.

Acara ini memerlukan biaya yang cukup tinggi karena menggunakan perlengkapan yang cukup mahal seperti emas dan kerbau. Dahulu acara Petik laut ini dapat dilaksanakan 2 (dua) kali dalam satu tahun, dengan sumber biaya yang berasal dari sumbangan masyarakat nelayan di sekitar desa, akan tetapi karena keadaan ekonomi yang semakin sulit sehingga acara "Petik laut" belum tentu sekali setahun dapat diadakan.

Salah satu faktor yang membuat kelembagaan adat cukup efektif dalam pengaturan sumberdaya kelautan dan perikanan adalah rasa kepemilikan yang tinggi terhadap peraturan yang telah ditetapkan. Masyarakat dengan kesadaran tinggi akan melakukan pengawasan baik secara langsung maupun tidak langsung terhadap berbagai aktivitas masyarakat dalam kaitannya terhadap sumberdaya kelautan dan perikanan. Menurut Astuti 
(2008), kepercayaan masyarakat nelayan terhadap mitos sangat mempengaruhi aktivitas melaut. Hampir semua masyarakat nelayan di desa Tanjung Luar percaya terhadap keberadaan mitos tersebut dan berpengaruh terhadap aktivitas melaut. Keberadaan acara "Petik laut" ini sangat menguntungkan bagi kelestarian dan pelestarian sumberdaya ikan karena berdasarkan keputusan dari masyarakat desa Tanjung Luar dan berdasarkan awigawig, atau ketentuan adat, desa selama 3 (tiga) hari setelah acara "Petik laut" nelayan tidak diperbolehkan melaut. Ikan-ikan yang sedang memijah akan sangat diuntungkan dengan keadaan ini.

\section{Simpulan}

Dari uraian di atas dapat dilihat bahwa desa Tanjung Luar secara administratif termasuk ke dalam wilayah Kecamatan Keruak Kabupaten Lombok Timur Nusa Tenggara Barat. Desa Tanjung Luar memiliki potensi perikanan yang tinggi karena merupakan salah satu desa yang terletak di pinggir pantai di Kabupaten Lombok Timur. Sebagian besar penduduknya bekerja sebagai nelayan.

Desa Tanjung Luar juga memiliki suatu kelembagaan yang bergerak di bidang pengelolaan sumberdaya perikanan, salah satunya adalah KMPL. Keikutsertaan masyarakat dalam upaya pengelolaan ini cukup tinggi, hal ini dibuktikan dengan melakukan penindakan yang tegas terhadap para nelayan yang tertangkap menggunakan bom atau potasium. Mereka juga antusius mengikuti program penanaman mangrove bersama.

Adat-istiadat yang ada di desa Tanjung Luar juga efektif untuk upaya pengelolaan sumberdaya perikanan, salah satu adat tersebut adalah ritual "Petik laut." Hampir semua masyarakat nelayan di desa Tanjung Luar percaya terhadap keberadaan mitos tersebut sehingga hal ini berpengaruh terhadap aktivitas melaut. 


\section{Daftar Pustaka}

Astuti, P. 2008. Pola Hubungan Patron-Client dalam Upaya Pengelolaan Sumberdaya Perikanan di Desa Tanjung Luar Kabupaten Lombok Timur Nusa Tenggara Barat. Semarang: Fakultas Perikanan dan Ilmu Kelautan. Universitas Diponegoro..

Badan Koordinasi Keluarga Berencana Nasional. 1994. Pembangunan Keluarga Sejahtera di Indonesia Berdasarkan UU No. 10 Tahun 1992 dan GBHN Tahun 1993. Jakarta: Kantor Menteri Kependudukan dan Koordinasi Keluarga Berencana Nasional..

BAPPENAS. 2005. Pengelolaan Sumber Daya Kelautan dan Perikanan Secara Terpadu dan Berkelanjutan yang Berpihak kepada Masyarakat Pesisir dan Nelayan Kecil. Jakarta: BAPPENAS.

Dinas Kelautan dan Perikanan Lombok Timur. 2004. Laporan Tahunan Tahun 2004. Lombok Timur: Dinas Kelautan dan Perikanan Lombok Timur.

Dinas Kelautan dan Perikanan Lombok Timur. 2006. Laporan Tahunan Tahun 2006. Lombok Timur: Dinas Kelautan dan Perikanan. Lombok Timur.

Kartodiarjo. 1994. Kebudayaan Pembangunan dalam Perspektif Sejarah. Yogyakarta: Gajah Mada University.

Mulyadi S. 2005. Ekonomi Kelautan. Jakarta: PT. Raja Grafindo Persada.

Peta Kabupaten Lombok Timur dan Desa Tanjung Luar. www.google.com Diakses pada tanggal 2 Juni 2009.

Undang-Undang Republik Indonesia nomor 31 tahun 2004. Tentang Perikanan.

Widodo, J. dan Suadi. 2006. Pengelolaan Sumber Daya Perikanan Laut. Yogyakarta: Gajah Mada University Press. 